\title{
ANALISIS JANUARY EFFECT PADA RETURN SAHAM \\ BERKAPITALISASI BESAR DAN KECIL DI BURSA EFEK JAKARTA \\ PADA TAHUN 2004-2007 \\ Christian Putra \\ Email: chris@yahoo.co.uk
}

\section{Penulis}

Christian adalah pengajar tidak tetap di Universitas Lampung dengan bidang peminatan pada mata kuliah keuangan dan perbankan.

\section{Abstract}

In the beginning of the year, stock's return has an abnormal return. Small capital stocks produce better return than the large capital stocks which listed in Bursa Efek Jakarta (BEJ). This anomaly is known as January Effect. That's why, when turn over especially occurs in the beginning of trading market activity, many investor will invest their assets in small capital stocks. This research tries to found out whether there is or there isn't January effect anomaly in Bursa Efek Jakarta in 2004 till 2007. This research uses non probability method which chooses 30 stocks in each category. The significance level of the research is always bigger than 0.05 and that result shows us that there is no January effect in Bursa Efek Jakarta (BEJ) from 2004 till 2007.

\section{Key Words}

Return, January Effect, Stocks 


\section{PENDAHULUAN}

January Effect dapat dikatakan sebagai salah satu contoh anomali pasar yang paling terkenal di seluruh dunia. Pada awal pergantian tahun, beberapa jenis saham mengalami return yang abnormal. Pada saat seperti itu, perhatian para investor akan terpusat pada saham - saham yang berkapitalisasi kecil, karena saham-saham tersebut cenderung untuk menghasilkan return yang lebih besar daripada saham-saham berkapitalisasi besar. Secara umum, hal ini terlihat jelas pada lima hari perdagangan pertama di bulan januari.

January Effect menjadi perhatian dunia sejak di perkenalkan oleh Roseff dan Kinney pada tahun 1976, walaupun sebenarnya telah di lakukan penelitian lebih dari 60 tahun yang lalu oleh Watcher pada tahun 1942. Penelitian Roseff dan Kinney berdampak lebi besar karena merupakan fakta pertama yang menjelaskan bahwa January Effect menjadi isu yang di minati dan sering dibahas dalam jurnal akademik maupun terapan, oleh para ekonom dan investor dunia.

Berbagai penelitian yang dilakukan oleh para ahli di dunia telah menunjukkan terjadinya January Effect pada pasar modal dunia. Berdasarkan hal tersebut maka di susunlah sebuah penelitian mengenai January Effect di Bursa Efek Jakarta pada periode 2004-2007.

\section{Pembatasan Masalah}

Masalah yang di kemukakan pada penelitian - penelitian sebelumnya mengenai January Effect sangat luas, maka dari itu penelitian ini dibatasi agar lebih terarah dan fokus sehingga mencapai hasil yang maksimal. Penelitian ini membahas mengenai apakah terdapat perbedaan rata0rata return saham berkapitalisasi besar dan kecil pada lima hari pertama perdagangan di bulan januari 2004-2007. pertimbangan pemilihan periode ini adalah karena perekonomian Indonesia mengalami perbaikan ke arah yang lebih stabil setelah krisis perekonomian 1997 


\section{Tujuan Penelitian}

Tujuan dari penelitian ini adalah:

1. Untuk mengetahui ada atau tidaknya perbedaan rata-rata return saham berkapitalisasi besar dan kecil di Bursa Efek Jakarta pada lima hari perdagangan pertama saham setelah tahun baru pada setiap bulan Januari pada tahun 2004-2007

2. Untuk memberikan informasi kepada para investor temtamg Jamuary Effect yang terjadi di BEJ.

\section{Landasan Teori}

\section{January Effect}

Jamuary Effect (Jones 2002) didefinisikan sebagai "The observed tendency for small-cap to be higher in Jamuary than in other months, during the first five trading days of that month".

\section{Tujuan Investasi}

Tujuan Investasi (Koetin 1996) adalah:

"Memperoleh penghasilan selama jangka waktu tertentu, menambahkan nilai modal yang di tempatkan dan menjaga terhadap inflasi, namu itu semua di lakukan denga risiko yangdapat ditolerir."

Jadi dalam keputusan memilihh investasi harus di perhitungkan tingkat pengembalian yang ddiharakan dengan risiko yang akan diperoleh. Pada umumnya semakin besar risiko yang dihadapi maka akan semakin tinggi pula tingkat pengembalian yang diharapkan. 


\section{Jenis - Jenis Investasi}

Secara garis besar, investasi dapat dikategorikan berdasarkan bentuk dan jangka waktu investasinya.

Menurut bentuknya, investasi dapat dibedakan menjadi dua ( Koetin 1996), yaitu:

1. Investasi berwujud (Tangible assets)

Investasi jenis ini antara lain berupa investasi aset dalam bentuk emas, tanah, rumah dan barang - barang tidak bergerak lainnya yang mempunyai bentuk riil

2. Investasi tidak berwujud (Intangible assets)

Investasi jenis ini antara lain berupa investasi aset dalam bentuk saham perusahaan, obligasi, dan surat berharga lainnya, serta aset lainnya yang tidak mempunyai bentuk riil

Investasi menurut bentuknya (Agus Sartono 1997) terbagi atas:

1. Investasi Jangka Pendek

Investasi jenis ini adalah merupakan jenis investasi yang waktu investasinya kurang dari satu tahun

2. Investasi Jangka Panjang

Investasi jenis ini adalah merupakan jenis investasi yang waktu investasinya lebih dari satu tahun. Investasi jangka panjang dibedakan lagi menjadi dua bagian, yaitu investasi yang jangka waktu investasinya kurang dari lima tahun dan investasi yang jangka waktu investasinya lebih dari lima tahun 


\section{Risiko Investasi}

Ada dua tipe risiko yang dihadapi oleh setiap investor dalam menginvestasikan dananya pada surat-surat berharga, yaitu: .

1. Risiko Sistematik

Yaitu merupakan risiko yang tidak dapat dihapuskan maupun dikurangi dengan mendiversifikasikannya kedalam portofolio. Oleh karena itu, Risiko sistematik juga disebut sebagai risiko pasar (market risk) karena fluktuasi ini disebabkan oleh faktor-faktor yang mempengaruhi semua perusahaan yang beroperasi

2. Risiko Sistematik

Yaitu merupakan risiko yang dapat dihapuskan maupun dikurangi dengan mendiversifikasikannya kedalam suatu kombinasi dengan investasi lainnya, yang kita sebut juga diversifikasi kedalam portofolio.

Oleh karena itu, Risiko ini juga disebut sebagai diversifiable risk.

Penjumlahan dari kedua jenis resiko ini disebut juga risiko total

\section{Pasar Modal yang Efisien}

Untuk menunjang kegiatan investasi yang efisien diperlukan sarana yang memadai, termasuk didalamnya adalah adanya suatu pasar modal yang efisien secara internasional

Berikut ini adalah kondisi yang harus di penuhi sebagai syarat untuk mewujudkan pasar modal yang efisien secara internasional, yaitu:

1. Informasi dapat di peroleh tanpa biaya dan tersedia bagu semua pelaku pasar modal

2. Partisipasi secara individu tidak akan mampu memperngaruhi harga saham

3. Semua partisipan modal dapat bersifat rasional (expected utility) 
Dengan dipenuhinya ketiga syarat tersebut maka pasar modal yang efisien secara internasional dapat terbentuk. Terdapat tiga kategori bentuk pasar modal yang efisiesn, yaitu Weak form efficiency, Semi strong efficiency dan strong efficiency. Hal ini dapat terlihat dalam gambar berikut ini

Gambar 1

Bentuk Pasar Modal Efisien

Strong efficiency

Semi strong efficiency

Weak strong efficiency

Sumber : (Suad Husnan 1998) 


\section{Anomali (keganjilan) Pasar}

Akhir-akhir ini banyak penelitian mengungkapkan berbagai anomali pada teori pasar yang dapat mendukung inefisiensi pasar. Berbagai anomali tersebut :

1. Within the month effect

Penelitian ini menunjukkan bahwa return saham cenderung positif selama setengah bulan pertama (lima belas hari pertama), sementara mulai dari pertengahan bulan rata-rata return adalan nol.

2. Monday effect

Sejumlah penelitian menunjukkan bahwa dari lima hari kerja dalam seminggu, hanya satu hari yaitu hari senin yang menunjukkan return negatif secara historis

3. The Presidential Cycle Effect

Beberapa peneliti menemukan hubungan antar return saham dengan tahuntahun pada masa pemerintahan.

4. Weekend Effect

Fenomena lain yang menunjukkan anomali pasar modal adalah weekend effect, yang menunjukkan pada hari senin, diperoleh return yang negatif dibandingkan return pada hari lainnya, dalam penelitian mengenai weekend effect yang telah disempurnakan diketahui bahwa sebenarnya weekend effect adalah monday effect yang diakibatkan oleh pengungkapan informasi yang buruk setelah penutupan perdagangan di hari jumat.

5. January Effect

Penelitian tentang return di Amerika Serikat secara konstan menunjukkan adanya perbedaan yang signifikan selama bulan Januari dibandingkan bulan yang lain dalam satu tahun.

Fenomena ini dikenal juga dengan nama The Year - End Effect 


\section{KERANGKA PEMIKIRAN}

\section{Gambar 2 \\ Kerangka Pemikiran Penelitian}

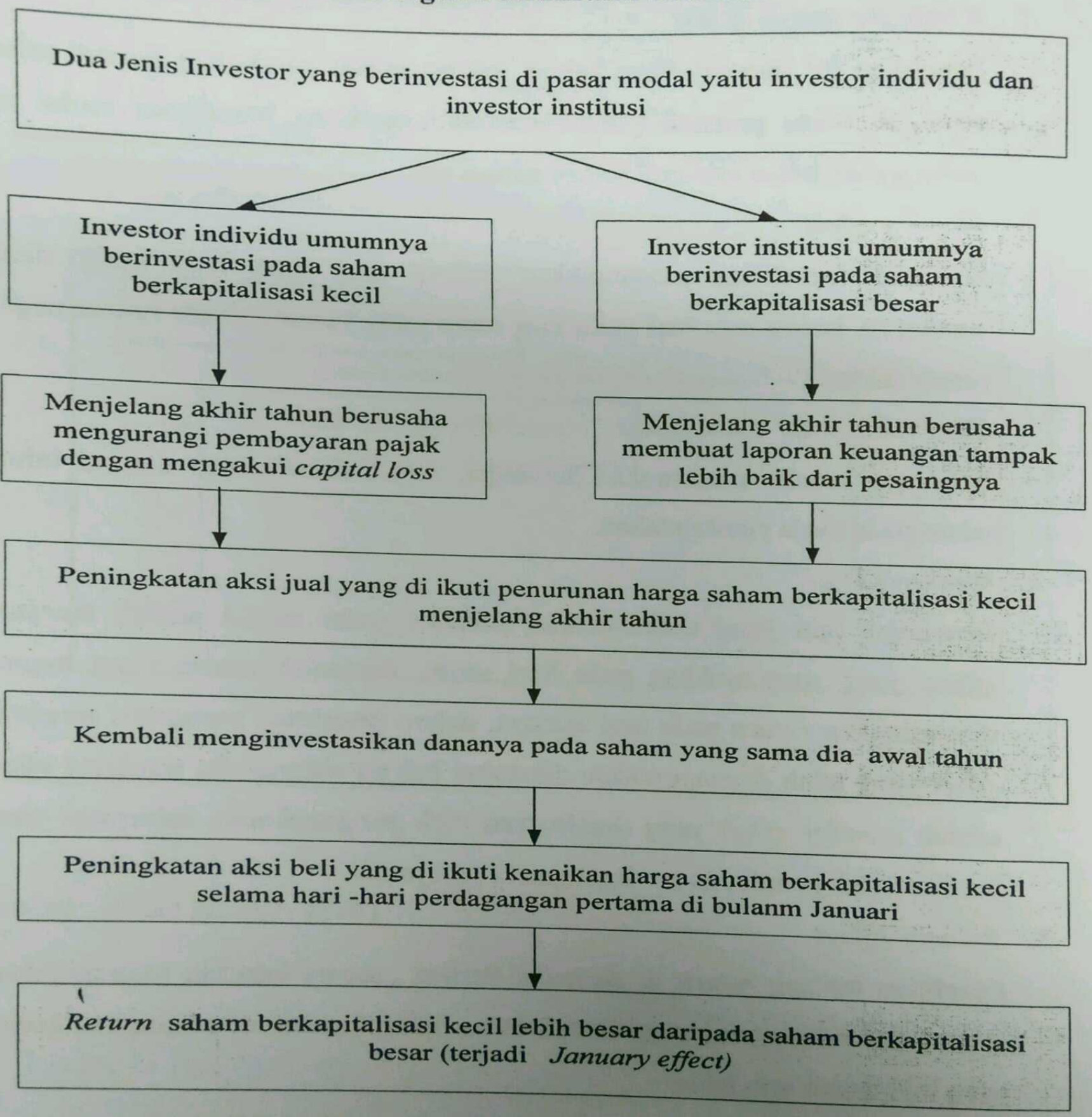

Sumber : data olahan 


\section{Hipotesis}

Untuk mengetahui terjadi atau tidaknya January Effect di BEJ pada periode 2004-2007 maka di buatlah suatu hipotesis sebagai berikut

H0 : Rata-rata return saham kapitalisasi kecil sama dengan rata-rata return saham berkapitalisasi besar selama lima hari perdagangan pertama di bulan Januari periode $\mathrm{i}$

Ha : Rata-rata return saham kapitalisasi kecil tidak sama dengan rata-rata return saham berkapitalisasi besar selama lima hari perdagangan pertama di bulan Januari periode $\mathrm{i}$

Periode $\mathrm{i}=$ tahun 2004-02007

Jika hasil signifikansi yang diperoleh dari hasil uji t ternyata lebih besar dari 0.05 maka H0 tidak ditolak, artinya Rata-rata return saham kapitalisasi kecil sama dengan rata-rata return saham berkapitalisasi besar selama lima hari perdagangan pertama di bulan Januari 2004-2007.

\section{METODOLOGI PENELITIAN}

\section{Subjek dan Objek Penelitian}

Subjek dari penelitian ini adalah saham berkapitalisasi kecil dan besar pada lima hari pertama perdagangan di bulan Januari, sedangkan objek variabel penelitiannya adalah perbedaaan rata-rata return saham berkapitalisasi besar dan kecil.

\section{Teknik Pengumpulan Data}

Pada penelitianini metode yang digunakan adalah non probability sampling dengan teknik purposive sampling, yaitu pangeambilan dsampel sesuai dengan kriteria yang telah di tentukan oleh si peneliti yang menyesuaikan dengan tujuan penlitian. 


\section{ANALISIS DAN PEMBAHASAN}

Berikut adalah data harga 30 saham yang berkapitalisasi besar dan kecil selama lima hari perdagangan pertama pada Januari 2004-2007.

\section{Tabel 1}

Saham-Saham Berkapitalisasi Besar

\begin{tabular}{|l|l|l|}
\hline No & Kode Saham & Saham \\
\hline 1 & AALI & Astra Argo Lestari \\
2 & ANTM & Aneka Tambang \\
3 & ASII & Astra Internasional \\
4 & BBRI & Bank Rakyat Indonesia \\
5 & BLTA & Berlian Laju Tanker \\
6 & BMRI & Bank Mandiri \\
7 & BRPT & Barito Pacific Timber \\
8 & BUMI & Bumi Resources \\
9 & CMNP & Citra Marga Nusaphala Persada \\
10 & GGRM & Gudang Garam \\
11 & GJTL & Gajah Tunggal \\
12 & INDF & Indofood Sukses Makmur \\
13 & INKP & Indah Kiat Pulp \& Paper \\
14 & INTP & Indocement Tunggal Prakasa \\
15 & MERK & Merck \\
16 & KLBF & Kalbe Farma \\
17 & LSIP & PP London Sumatra \\
18 & MEDC & Medco Energi International \\
19 & PGAS & Perusahaan Gas Negara \\
20 & PNBN & Bank Pan Indonesia \\
21 & LTLS & Lautan Luas \\
22 & PTBA & Tambang Batubara Bukit Asam \\
23 & SMCB & Holcim Indonesia \\
24 & SMRA & Summarecon Agung \\
25 & TINS & Timah \\
26 & TKIM & Pabrik Kerta Tjiwi Kimia \\
27 & UNTR & United Tractors \\
28 & UNVR & Unilever Indonesia \\
29 & HMSP & HM Sampoerna \\
30 & AQUA & Aqua Golden Missipi \\
\hline
\end{tabular}

Sumber : (BEJ 2008) 
Tabel 2

Saham-Saham Berkapitalisasi Kecil

\begin{tabular}{|l|l|l|}
\hline No & Kode Saham & Saham \\
\hline 1 & INAI & Indal Alumunium Industry \\
2 & JKSW & Jakarta Kyoei Steel Work \\
3 & JPRS & Jaya Pari Steel Corp. Ltd \\
4 & SIMA & Siwani Makmur \\
5 & TBLA & Tunas Baru Lampung \\
6 & JPFA & Japfa \\
7 & CEKA & Cahaya Kalbar \\
8 & PBRX & Pan Brothers Tex \\
9 & ARNA & Arwana Citramulia \\
10 & INCF & Indocitra Finance \\
11 & SMDM & Suryamas Dutamakmur \\
12 & SIIP & Suryainti Permata \\
13 & AHAP & Asuransi Harta Dana Aman Pratama \\
14 & MREI & Maskapai Reasuransi Indonesia \\
15 & BVIC & Bank Victoria International \\
16 & MIRA & Mitra Rajasa \\
17 & SAFE & Steady Safe \\
18 & TIRT & Tirta Mahakam Resource \\
19 & CTTH & Citatah Industry \\
20 & PICO & Pelangi Indah Canindo \\
21 & PRAS & Prima Alloy Steel \\
22 & MYRX & Hanson International \\
23 & WAPO & Wahana Phonix Mandiri \\
24 & VOKS & Voksel Electric \\
25 & CKRA & Ciptojaya Kontrindeksa \\
26 & META & Nusantara Infrastructur \\
27 & DART & Data Anggada Realty \\
28 & MLPL & Multipolar \\
29 & MBAI & Multibreeder Adiarama Indonesia \\
30 & KDSI & Kedawung Setia Industrial \\
& & \\
\hline
\end{tabular}

Sumber : (BEJ 2008) 


\section{Proses Pengujian}

\section{Tahun 2004}

\section{Uji Homoskedastisitas}

H0 : Varian kedua populasi untuk tahun 2004 adalah sama

Ha : Varian kedua populasi untuk tahun 2004 adalah tidak sama

\section{Tabel 3}

Test of Homogenity of Variances

\begin{tabular}{|l|ll|ll|l|}
\hline $\begin{array}{l}\text { Levene } \\
\text { statistic }\end{array}$ & df1 & df2 & & df3 \\
\hline .023 & & 1 & & 8 & .882 \\
\hline
\end{tabular}

Sumber : hasil olahan SPSS

Untuk tahun 2004, besar koefisien levene nya adalah 0.023 dengan nilai signifikansi 0.882 . Karena nilai sig. $>0.05$ maka Ho tidak ditolak, yang artinya Varian kedua populasi untuk tahun 2004 adalah sama sehingga proses pengolahan data tahun 2004 dapat dilanjutkan.

\section{Uji-t.}

H0: Rata-rata return saham kapitalisasi kecil sama dengan rata-rata return saham berkapitalisasi besar selama lima hari perdagangan pertama di bulan Januari tahun 2004

Ha : Rata-rata return saham kapitalisasi kecil tidak sama dengan rata-rata return saham berkapitalisasi besar selama lima hari perdagangan pertama di bulan Januari tahun 2004 
Tabel 4

Independent Samples Test

\begin{tabular}{|l|l|l|l|l|l|}
\hline & \multicolumn{2}{|c|}{$\begin{array}{c}\text { Levene's Test } \\
\text { For } \\
\text { Equality of } \\
\text { Variances }\end{array}$} & \multicolumn{4}{|c|}{ t-test for Equality of Means } \\
\hline & $\mathrm{F}$ & Sig. & $\mathrm{t}$ & $\mathrm{df}$ & Sig. (2-tailed) \\
\hline & .023 & .882 & -.350 & 8 & .735 \\
\hline $\begin{array}{l}\text { Equal Variances } \\
\begin{array}{l}\text { Assumed } \\
\text { Equal Variances } \\
\text { not assumed }\end{array}\end{array}$ & & -.350 & 7.984 & .735 \\
\hline
\end{tabular}

Sumber : hasil olahan SPSS

Karena nilai sig, (2-tailed) pada equal variances assumed yaitu sebesar 0.735 maka H0 tidak ditolak yang artinya Rata-rata return saham kapitalisasi kecil sama dengan rata-rata return saham berkapitalisasi besar selama lima hari perdagangan pertama di bulan Januari tahun 2004.

Ini berarti dari hasil pengujian terlihat bahwa January Effect tidak terjadi di BEJ pada tahun 2004

\section{Tahun 2005}

\section{Uji Homoskedastisitas}

HO : Varian kedua populasi untuk tahun 2005 adalah sama

Ha : Varian kedua populasi untuk tahun 2005 adalah tidak sama

\section{Tabel 5}

Test of Homogenity of Variances (2005)

\begin{tabular}{|c|c|c|c|}
\hline $\begin{array}{l}\text { Levene } \\
\text { statistic }\end{array}$ & df1 & df2 & df3 \\
\hline 2829 & 1 & 8 & .131 \\
\hline
\end{tabular}

Sumber : hasil olahan SPSS 
Untuk tahun 2005, besar koefisien levene nya adalah 2.829 dengan nilai signifikansi 0.131. Karena nilai sig. $>0.05$ maka Ho tidak ditolak, yang artinya Varian kedua populasi untuk tahun 2005 adalah sama sehingga proses pengolahan data tahun 2005 dapat dilanjutkan.

Uji-t.

H0: Rata-rata return saham kapitalisasi kecil sama dengan rata-rata return saham berkapitalisasi besar selama lima hari perdagangan pertama di bulan Januari tahun 2005

Ha : Rata-rata return saham kapitalisasi kecil tidak sama dengan rata-rata return saham berkapitalisasi besar selama lima hari perdagangan pertama di bulan Januari tahun 2005

\section{Tabel 6}

Independent Samples Test

\begin{tabular}{|l|l|l|l|l|l|l|}
\hline & \multicolumn{3}{|c|}{$\begin{array}{c}\text { Levene's Test } \\
\text { For } \\
\text { Equality of } \\
\text { Variances }\end{array}$} & \multicolumn{3}{|c|}{ t-test for Equality of Means } \\
\hline & $\mathrm{F}$ & Sig. & $\mathrm{t}$ & $\mathrm{df}$ & Sig. (2-tailed) \\
\hline & 2.829 & .131 & -.463 & & 8 & .656 \\
\hline $\begin{array}{l}\text { Equal Variances } \\
\begin{array}{l}\text { Assumed } \\
\text { Equal Variances } \\
\text { not assumed }\end{array}\end{array}$ & & & -.463 & 6.640 & .658 \\
\hline
\end{tabular}

Sumber : hasil olahan SPSS

Karena nilai sig, (2-tailed $)$ pada equal variances assumed yaitu sebesar 0.656 maka $\mathrm{H} 0$ tidak ditolak yang artinya Rata-rata return saham kapitalisasi kecil sama dengan rata-rata return saham berkapitalisasi besar selama lima hari perdagangan pertama di bulan Januari tahun 2005. 
Ini berarti dari hasil pengujian terlihat bahwa Jamuary Fffeer tidak terjadi di BEJ pada tahun 2005

\section{Tahun 2006}

\section{Uji Homoskedastisitas}

HO : Varian kedua populasi untuk tahun 2006 adalah sama

Ha : Varian kedua populasi untuk tahun 2006 adalah tidak sama

\section{Tabel 7}

Test of Homogenity of Variances

(2006)

\begin{tabular}{|l|ll|ll|l|}
\hline $\begin{array}{l}\text { Levene } \\
\text { statistic }\end{array}$ & df1 & df2 & & df3 \\
\hline .335 & & 1 & & 8 & .579 \\
\hline
\end{tabular}

Sumber : hasil olahan SPSS

Untuk tahun 2006, besar koefisien levene nya adalah 0.335 dengan nilai signifikansi 0.579 . Karena nilai sig. $>0.05$ maka Ho tidak ditolak, yang artinya Varian kedua populasi untuk tahun 2006 adalah sama sehingga proses pengolahan data tahun 2006 dapat dilanjutkan.

\section{Uji-t.}

HO: Rata-rata return saham kapitalisasi kecil sama dengan rata-rata return saham berkapitalisasi besar selama lima hari perdagangan pertama di bulan Januari tahun 2006

Ha : Rata-rata return saham kapitalisasi kecil tidak sama dengan rata-rata return saham berkapitalisasi besar selama lima hari perdagangan pertama di bulan Januari tahun 2006 


\section{Tabel 8}

Independent Samples Test

\begin{tabular}{|l|l|l|l|l|l|l|}
\hline & \multicolumn{3}{|c|}{$\begin{array}{c}\text { Levene's Test } \\
\text { For } \\
\text { Equality of } \\
\text { Variances }\end{array}$} & \multicolumn{4}{|c|}{ t-test for Equality of Means } \\
\hline & $\mathrm{F}$ & Sig. & $\mathrm{t}$ & $\mathrm{df}$ & Sig. (2-tailed) \\
\hline & .335 & .579 & -.985 & 8 & .353 \\
\hline $\begin{array}{l}\text { Equal Variances } \\
\begin{array}{l}\text { Essumed } \\
\text { Equal Variances } \\
\text { not assumed }\end{array}\end{array}$ & & & -.985 & 6.563 & .360 \\
\hline
\end{tabular}

Sumber : hasil olahan SPSS

Karena nilai sig, (2-tailed) pada equal variances assumed yaitu sebesar 0.656 maka $\mathrm{H} 0$ tidak ditolak yang artinya Rata-rata return saham kapitalisasi kecil sama dengan rata-rata return saham berkapitalisasi besar selama lima hari perdagangan pertama di bulan Januari tahun 2006.

Ini berarti dari hasil pengujian terlihat bahwa January Effect tidak terjadi di BEJ pada tahun 2006

\section{Tahun 2007}

\section{Uji Homoskedastisitas}

HO : Varian kedua populasi untuk tahun 2007 adalah sama

$\mathrm{Ha}$ : Varian kedua populasi untuk tahun 2007 adalah tidak sama

\section{Tabel 9}

Test of Homogenity of Variances

\begin{tabular}{|l|ll|ll|l|}
\hline $\begin{array}{l}\text { Levene } \\
\text { statistic }\end{array}$ & df1 & df2 & & df3 \\
\hline .223 & & 1 & & 8 & .649 \\
\hline
\end{tabular}

Sumber : hasil olahan SPSS

Untuk tahun 2007, besar koefisien levene nya adalah 0.223 dengan nilai signifikansi 0.649 . Karena nilai sig. $>0.05$ maka Ho tidak ditolak, yang artinya 
Varian kedua populasi untuk tahun 2007 adalah sama sehingga proses pengolahan data tahun 2007 dapat dilanjutkan.

\section{Uji-t.}

H0: Rata-rata return saham kapitalisasi kecil sama dengan rata-rata return saham berkapitalisasi besar selama lima hari perdagangan pertama di bulan Januari tahun 2007

Ha : Rata-rata return saham kapitalisasi kecil tidak sama dengan rata-rata return saham berkapitalisasi besar selama lima hari perdagangan pertama di bulan Januari tahun 2007

\section{Tabel 10}

Independent Samples Test

\begin{tabular}{|l|l|l|l|l|l|}
\hline & \multicolumn{3}{|c|}{$\begin{array}{c}\text { Levene's Test } \\
\text { For } \\
\text { Equality of } \\
\text { Variances }\end{array}$} & \multicolumn{4}{|c|}{ t-test for Equality of Means } \\
\hline & $\mathrm{F}$ & Sig. & $\mathrm{t}$ & $\mathrm{df}$ & $\mathrm{Sig}$. (2-tailed) \\
\hline $\begin{array}{l}\text { Equal Variances } \\
\text { Assumed } \\
\text { Equal Variances } \\
\text { not assumed }\end{array}$ & .223 & .649 & -.073 & 8 & .944 \\
\hline
\end{tabular}

Sumber : hasil olahan SPSS

Karena nilai sig, (2-tailed) pada equal variances assumed yaitu sebesar 0.944 maka $\mathrm{H} 0$ tidak ditolak yang artinya Rata-rata return saham kapitalisasi kecil sama dengan rata-rata return saham berkapitalisasi besar selama lima hari perdagangan pertama di bulan Januari tahun 2007.

Ini berarti dari hasil pengujian terlihat bahwa January Effect tidak terjadi di BEJ pada tahun 2007 


\section{KESIMPULAN DAN SARAN}

Setelah proses analisis dan pengolahan data selesai dilakukan dapat dipeoleh kesimpulan yang merupakan hasil dari penelitian mengenai fenomena January Effect di Bursa Efek Jakarta pada tahun 2004-2007. Berdasarkan kesimpulan tersebut, dapat diberikan saran yang perlu diperhatikan oleh investor berkaitan dengan fenomena January Effect dalam pengambilan keputusan investasi.

\section{Kesimpulan}

Berdasarkan analisis dan hasil penghasilan data yang telah dilakukan, dapat diperoleh kesimpulan bahwa berdasarkan uji-t, diketahui bahwa tidak terdapat perbedaan rat-rata return saham berkapitalisasi besar dan kecil di Bursa Efek Jakarta pada lima hari pertama perdagangan saham setelah tahun baru pada setiap bulan januari pada tahun 2004-2007, artinya January Effect tidak terjadi di bursa efek Jakarta pada tahun 2004-2007.

\section{Saran}

Berdasarkan kesimpulan di atas, terdapat beberapa saran yang hendaknya diperhatikan oleh para investor dalam pengambilan keputusan investasinya. Penulis juga berharap agar saran-saran berikut dapat bermanfaat bagi para investor:

1. Karena hasil analisis dan proses pengolahan data pada penelitian ini menunjukan bahwa January Effect tidak terjadi di Bursa efek Jakarta, maka sebaiknya para investor tidak mengambil keputusan investasiberdasarkan fenomena tersebut.

2. Disarankan kepada para investor untuk tetap menanamkan modalnya pada saham-saham dengan nilai kapitalisasi besar daripada saham-saham dengan nilai kapitalisasi kecil pada lima hari perdagangan saham pada awal bulan januari karena rata-rata return saham berkapitalisasi besar lebih tinggi dibandingkan rata-rata return saham berkapitalisasi kecil. 
3. Dengan tidak terbuktinya fenomena Jamury Effect di Bursa Efek Jakarta, diharapkan ada penelitian lebih lanjut mengenai permasalahan ini.

4. Karena teori yang menjelaskan tentang January Effect masih langka,diharapkan penelitian inidapat digunakan sebagai informasi bagi peneliti selanjutnya.

\section{DAFTAR PUSTAKA}

Aritonang R., Lerbin R., 2002, Peramalan Bisnis, Ghalia Indonesia. Jakarta

Haugen, Robert A. and Phillipe Jorion., 1996, 'The January Effect: still There After These Years', Vol. 52, Issue 1, PP 1-16, Financial Analyst Journal

Home, Van C. dan M,Jr.Wachowi, 1997, Prinsip-Prinsip Manajemen Keuangan, Edisi 9, Salemba Empat, Jakarta

Suad Husnan, 1998, Dasar-Dasar Teori Portofolio \& Analisis Sekuritas, Edisi ketiga, UPP AMP YKPN, Yogyakarta

Johnston, Ken and Don R.Cox, 1996, 'The Influence Of Tax Loss Selling By Individual Investor On Explanning The January Effect', Vol 35, Issue 1, PP 53-65, Journal Of Business And Economics

Jones, Charles P. Investments, 2002, Analysis and Management, Eight Edition, John Willey and Sons, Inc., North Carolina

Keown., 1997, Dasar-dasar Manajemen keuangan. Buku satu, Penerbit Salemba Empat, . Jakarta

Keotin, E.A., 1996, Analisis Pasar Modal, Pustaka Sinar Harapan, Jakarta

Reilly,Frank K. and Keith C. Brown, 1997, Investment Analysis and Portfolio Management, Fifth Edition, The Dryden Press, Florida.

Sartono, R.Agus, 1997, Manajemen Keuangan. Edisi Ketiga, BPFE, Yogyakarta

Sunariyah, 1997, Pengantar Pengetahuan Pasar Modal, Unit penerbit dan percetakan Akademi Manajemen Perusahaan YKPN, Yogyakarta 
Supranto, J., 1996, Statistik, Teori dan aplikasi, Jilid 1 1. Edisi kelima, Penerbit Erlangga , Jakarta..

Van Horne, James C. and John Wachowiz Jr., 1998, Fundamental Of Financial Management, Tenth Edition, Prentice Hall Inc., New Jersey

Winger, Bernart J.. dan Frasca, Raplh R, 1995, Investment: An In troduction to Analysis and Planning, Thirth Edition, Prentice-Hall Inc, New Jersey

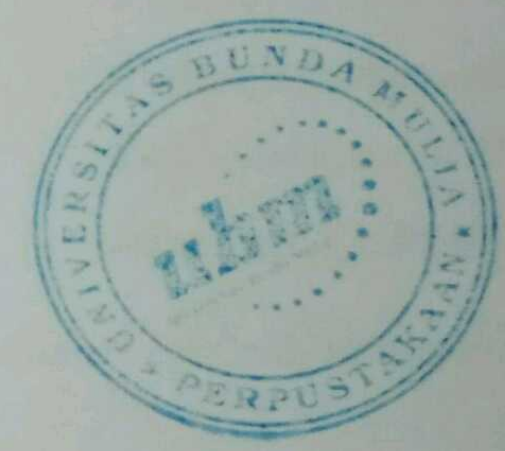

